DOI: https://doi.org/10.34069/AI/2021.47.11.7

How to Cite:

Rybinska, Y., Loshenko, O., Kurapov, A., Ponochovna-Rysak, T., \& Kholmakova, Y. (2021). The change in the concept of virtue during the COVID-19 pandemic. Amazonia Investiga, 10(47), 62-69. https://doi.org/10.34069/AI/2021.47.11.7

\title{
The change in the concept of virtue during the COVID-19 pandemic
}

\section{Переосмислення поняття доброчесності під час пандемії COVID-19}

Received: September 15, 202

Abstract

The purpose of the article is to cover the change in the concept of virtue during the COVID-19 pandemic, show its connection with human values and ethics. Virtue is the highest spiritual quality of a person. The main virtues include wisdom, courage, justice, moderation, responsiveness, loyalty, modesty, generosity and many others that affect all aspects of human life. Despite the recognized value of virtue as a system of moral guidelines, its concept is fraught with disputes about whether it is really generally valid, as well as about the problem of the effectiveness of virtue as a universal guideline and criterion for moral choice and its relevance in modern moral experience. This article argues that the most significant shift in the concept of virtue during the pandemic was the rethinking and increased awareness of the importance of such virtues as solidarity and moral responsibility, as well as aspects of relationships with people such as kindness, compassion, and empathy. It is proved that the concept of virtue has moved from a question of choice to the category of necessity, the most important guideline and guarantee of the common good.
Accepted: November 2, 2021

Written by:

Yuliia Rybinska ${ }^{29}$

https://orcid.org/0000-0003-2185-7890

Oleksandra Loshenko ${ }^{30}$

https://orcid.org/0000-0002-3303-3162

Anton Kurapov ${ }^{31}$

https://orcid.org/0000-0002-1286-9788

Taisiia Ponochovna-Rysak ${ }^{32}$

https://orcid.org/0000-0002-2107-3343

Yuliia Kholmakova ${ }^{33}$

https://orcid.org/0000-0002-9340-6012

\section{Анотація}

Мета статті полягає в обгрунтуванні переосмислення поняття доброчесності під час пандемії COVID-19 та відображенні його зв'язку з людськими цінностями та етикою. Доброчесність - це найвища духовна цінність людини. До основних рис доброчесності належать: мудрість, мужність, справедливість, поміркованість, чуйність, вірність, скромність, щедрість та багато інших, які впливають на всі аспекти людського життя. Незважаючи на визнану цінність доброчесності, як системи моральних орієнтирів, ऑii концепція суперечить тому, чи дійсно вона $\epsilon$ загальноприйнятою і чи $є$ вона ефективним універсальним ціннісним орієнтиром та критерієм морального вибору у сучасному моральному досвіді. У статті з'ясовано, що найбільш значним зрушенням у концепції доброчесності під час пандемії стало переосмислення та посилення усвідомлення важливості таких якостей, як солідарність та моральна відповідальність, а також таких особливостей відносин між людьми, як доброта, співчуття та співпереживання.

\footnotetext{
${ }^{29}$ Doctor of Pedagogical Sciences, Professor, Head of the Foreign Philology Department, Kyiv National University of Culture and Arts, Ukraine.

${ }^{30} \mathrm{PhD}$ in Psychology, Associate Professor, Department of Experimental and Applied Psychology, Taras Shevchenko National University of Kyiv, Ukraine.

${ }^{31} \mathrm{PhD}$ in Psychology, Associate Professor, Department of Experimental and Applied Psychology, Taras Shevchenko National University of Kyiv, Ukraine.

${ }^{32} \mathrm{PhD}$ in Pedagogical Sciences, Associate Professor, Department of Foreign Philology, Kyiv National University of Culture and Arts, Ukraine.

${ }^{33}$ Lecturer, Department of Foreign Philology, Kyiv National University of Culture and Arts, Ukraine.
} 


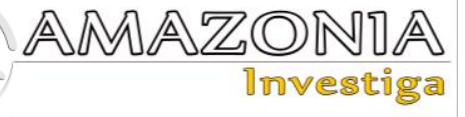

Keywords: virtue, COVID-19, values, pandemic, solidarity, moral responsibility.

Доведено, що поняття доброчесності перейшло від питання вибору до категорії необхідності, як найважливішого орієнтира та гарантії загального блага.

Ключові слова: доброчесність, COVID-19, цінності, пандемія, солідарність, моральна відповідальність.

\section{Introduction}

When the COVID-19 pandemic broke out, it raised various ethical dilemmas concerning ageism, health care prioritization, and even racism. At the same time, an unexpected consequence of the pandemic was the raised issue of virtue; in fact, one could speak of a changed concept of virtue itself. Certainly, the most basic virtues, core principles, remain unchanged for centuries. At the same time, despite the tendency to permanence, a virtue not once underwent changes during human history, especially accelerated by global crises. This is exactly what happened during the COVID-19 pandemic.

The scientific analysis of COVID-19 is dominated by medical issues related to treatment and prevention. At the same time, sociologists must keep track of emerging social orders, in which new conventions, feelings of solidarity and awareness of interdependence with others are formed. They find that there is a whole new attitude towards many aspects of virtue, new types of daily practice, and with it many unexpected questions.

Shared circumstances and tragedy unite people, increasing empathy and compassion. The unprecedented nature of the pandemic is that it has affected every person on earth, and this happened in the age of the Internet, at a time when people around the world are more interconnected than ever. As humanity moved from experiencing everyday life as something new and strange to exploring new forms of social consciousness, cohesion and disunity, it discovered a new norm, a new culture of the pandemic, where virtue became one of the key concepts. People all over the world had to reconsider their attitude towards their obligations to each other. Thus, the study of the new role of virtue in the present reality is relevant.

Over the past year, it has often been said that the world will never be the same. To understand what these phrases mean in the context of a new attitude towards virtue, it is necessary to understand what changes have occurred in the

moral identity of people. Now it is impossible to predict what it will finally become and how, as a result, the role of the main aspects of virtue will change, but it is possible to fix a number of significant changes in people's behavior. These changes are likely to entail changes in selfperception, leave traces in the minds of people and affect the attitude towards virtue and, accordingly, their actions.

Thus, there was a rethinking of the values of the entire population of the earth. As is well known, virtue expresses the individualization and arbitrariness of morality; it is the manifestation of morality in the individual, which becomes the motivation for behavior. Virtue is precisely active good, a fundamental moral concept that characterizes the readiness and ability of a person to consciously do good. However, few have pondered the great hidden power of virtue as a rescue mechanism in times of crisis, and this is the uniqueness of the current situation.

The aim of this research is to analyze studies dedicated to the COVID-19 pandemic using qualitative methods and explore what authors write on the changes in the concept of virtue in this connection. Further, the research aims to draw conclusions about the nature of these changes and the factors behind them.

\section{Literature Review}

Fahlquist (2021) stresses that the COVID-19 outbreak made it clear that both governments and individuals need to take moral responsibility to overcome the pandemic. All together and each separately must understand that it is solidarity and awareness of the responsibility that will lead to success. It was the pandemic that helped to see how everything is interconnected; even one person's exit from the house endangers the lives of his neighbors. Similarly, Morrell (2020) writes that the pandemic made people start thinking about "duties and consequences." Interestingly, the author describes that the concept of virtue can indeed change over time and gives the example of the Spartans and Athenians. Thus, the very 
essence of virtue and its various manifestations are very much tied to the current circumstances. The author also reflects on how the pandemic made people aware, more than ever before, that "individual virtues tied to civic virtues." The author also offers an interesting point of view that "like muscles, virtues can be thought of as emotions that have been trained." Training one's own virtue became an essential skill during the pandemic.

Xafis et al. (2020) discuss the diversity of ethical issues that emerged during the pandemic and that it exposed many of the problems of society, including injustice, inequality, and so on. This is difficult to deny because it is the global crisis, like nothing else, which can make the global problems of society explicit, as they are exacerbated in difficult times. At the same time, this was one of the reasons why people began to think more about the importance of virtue and realized its importance. The authors highlight that "the need to set aside differences and collaborate on global issues that impact on our health, well-being, and survival has become increasingly evident." This calls for the virtue of solidarity. The study by Tomasini (2021) explores the concept of solidarity during the pandemic from different perspectives. The author goes beyond many other studies and considers this virtue from a biocentric perspective and its disruptive aspects. Nevertheless, there is no denying that "one striking feature of this pandemic is how it bound people together to stand in solidarity against COVID-19, with the common purpose." Obviously, solidarity is a virtue, the importance of which was revealed in a special way during the pandemic. Jo et al. (2021) study community efforts aimed at coping with the COVID-19 pandemic. Although the research focused on identifying specific patterns of the process, it provides interesting observations concerning the expression of support and kindness. For example, many people expressed a desire to help people in their neighborhood and made an effort to learn new skills (such as producing PPE) by offering their help completely selflessly, despite the danger. In addition, members of the community tried to maintain communication in the virtual environment. Online interactions and conversations contributed to a greater sense of bonding among the neighbors. The authors conclude that "citizens can effectively contribute towards disaster relief, such as that required by the COVID-19 pandemic." The study showed that people were active, cooperated with each other, and acted in the interests of others.
A very interesting study was presented by Van Bavel et al. (2020). In the section "Disaster and 'panic' the authors claim that although there is a common belief that when in panic, people act out of self-preservation, often endangering the survival of all, and some used this idea to explain the COVID-19 pandemic's "panic buying," the picture is indeed the opposite. Although some people do act selfishly, it is cooperation and norm-governed behavior that are coming to the fore during emergencies and disasters. Thus, the question is, what are the factors that make people collaborate rather than compete in response to a crisis; for example, the authors mention such a factor as "emerging sense of shared identity and concern for others." Christner et al. (2020) also explore "the main psychological and social factors that motivate people to follow social distancing regulations." By using a questionnaire for data collection, the authors identified that moral judgment and empathy were the main factors. The findings suggest that social distancing can be classified as moral behavior. The authors state that humans tend to seek contact when confronted with a threat. This fact helps to understand the reason behind the change of attitudes toward virtue in general: from a personality trait to necessity, something that can be relied on in times of global threat.

Another interesting and offbeat study was presented by O'Brolcháin \& Brereton (2021), which discusses the COVID-19 pandemic and virtue ethics, using movies The Andromeda Strain (1971) and Contagion (2011) for comparison. It touches on many different issues, including the environmental crisis, the cost of the prosperity of human civilization, and inequality, which became especially pronounced during the pandemic. Along with this, the authors contemplate how fragile is the "social contract governing society." The important conclusion is that it is (as disaster movies show) global threats that recall the importance of solidarity; they reveal humanity's vulnerability and suggest the solutions of responsiveness to the facts and collective cooperation.

In addition, the report with recommendations by Deutscher Ethikrat or German Ethics Council (2020), although it concerns Germany, provides valuable information regarding solidarity and responsibility during the pandemic. It states that solidarity "never exists automatically," but "the impulse to help others may initially emanate from the elementary human compassion that almost everyone feels in the face of serious threats to others." At such moments, the attitude 


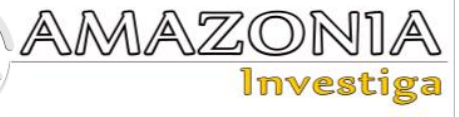

towards such previously neglected values changes.

Cheng et al. (2020) discuss the connection between wearing masks and altruism and solidarity during the pandemic. The authors point out that usually people wear masks to protect themselves but the COVID-19 pandemic showed that the main purpose was to protect others. They conclude that "mass masking...shifts the focus from self-protection to altruism, actively involves every citizen, and is a symbol of social solidarity in the global response to the pandemic." Continuing with the theme of solidarity, the study by Igwe et al. (2020) describes how solidarity and social behavior helped various communities, such as rural, urban and city dwellers, to manage the pandemic. The research confirmed that during the COVID-19 pandemic, "communities came together to support each other, educate and raise awareness about the disease and support vulnerable groups." The authors highlight that it is "the spirit of cooperation in solving mutual problems" that "helped people cope with the pandemic hardship." The article also discusses such a factor as social networks that contributed to the spirit of collectiveness during the lockdown and enhanced social bonds. The authors conclude that "solidarity - coming together by having shared interest, goals and mutual benefits - enhanced social and community cohesion during the pandemic."

The article by Jerry (2020) focuses on such virtues as responsibility and accountability in the case of healthcare providers. Of course, there are various laws governing medical practice; virtue has also always been an important guideline in health care. Nevertheless, during the pandemic, many moral and ethical issues arose at once, which the current generation has never faced. Therefore, in the area of healthcare, too, there is confirmation that the COVID-19 pandemic forced people to reconsider the attitude towards virtue, realizing this as a reliable basis for making decisions in uncertain circumstances. Continuing this thought, Agazzi (2020) also talks about the difficulty of making ethically acceptable decisions during a pandemic and the difference between moral and ethical-political obligations. The author concludes that "ethics committees should institutionally exist in hospitals." It turns out that virtue offers support even where laws cannot.

Pfattheicher et al. (2020) conducted a very important study. The authors surveyed participants from various Western countries to

examine the interrelationships between compliance to physical distancing and empathy. The results showed that for most people, empathy was an emotional basis motivating them to adhere to physical distancing and wearing a mask. Moreover, the authors conclude that "we can actually use empathy to promote the motivation in people to follow these two important measures." Thus, here the virtue in the form of empathy becomes not just quality but a solution to the problem. Similarly, in his article, Chávez-Segura (2020) claims that "compassion becomes the core element - or antidote - to end the global pandemic of fear, greed and ignorance." The author uses Hindu mythology as an example to explain that only liberation from the egotistic approach can bring humanity out of the crisis. The article leads to the conclusion that the pandemic situation provides an opportunity "to build a new world order, one with compassion and loving-kindness as an opportunity to enhance global development based on justice and solidarity." Thus, since the pandemic is a global event, it can give rise to the creation of a new global identity.

\section{Methodology}

The methodology of the survey is based on such methods as study, analysis and generalization which helped to examine the nature of virtue during the COVID-19 pandemic, and analytical methods that were used to analyze scientific papers in medicine, sociology, economy, and philosophy.

The given study considers 16 articles on the topic of the COVID-19 pandemic and its relation to the concept of virtue ethics and moral qualities. It compares what the authors write about the attitudes towards virtue in the context of the pandemic, how they changed, and factors that provoked these changes, as well as identifies similarities in their opinions. The given work represents qualitative descriptive research with content analysis.

\section{Results and Discussion}

The coronavirus pandemic is a global event, and it has affected every person in the global world. Various studies suggest that issues of moral qualities and values, in general, have arisen during the outbreak of COVID-19. The article by Fowers et al. (2021) focuses on the virtues of courage, justice, and practical wisdom as key virtues during the pandemic, but authors point out that "many other virtues... have come to the fore in 2020 as well". Moreover, practical 
wisdom is a virtue that "guides the expression of other virtues". During the pandemic, circumstances arose that required all people to show a special manifestation of practical wisdom, as well as called for moral responsibility to be courageous. Fowers et al. (2021) discuss the interrelationship between individual and collective virtues during the pandemic: since everyone around has common interests, strives for one goal, they have to manifest individual virtues, creating "collective encouragement and support for virtuous action" that will encourage every individual to demonstrate necessary qualities. Thus, no one could deny that of all the virtues that have declared their importance in the context of the pandemic, solidarity is one of the first to come to mind. Galang et al. (2021), in their report, succinctly highlight the importance of virtue ethics in dealing with the COVID-19 pandemic. According to the authors, "the virtue of solidarity is a reminder that everyone is in this crisis together and that each is responsible for all." Any crisis makes everyone who is affected feel responsible. In this case, every person on earth. Thus, the pandemic essentially forced everyone to rethink how much everyone on the planet, especially during a crisis, depends on each other, like cards in a house of cards, and how important solidarity and the ability to act in a coordinated manner and in one direction are in this regard.

From the very beginning of the quarantine, one could often hear that before that, humanity was a single organism, and with the onset of the pandemic, the situation changed dramatically, and the world broke into small parts, closing the borders. In addition, each country began to fight the spread of the virus on its own. Nevertheless, despite the closure of borders and the seeming distance of countries from each other and social distance between people, the pandemic has in many ways brought humanity closer and united. Mendes (2020) writes that "ironically...people are increasingly making the effort to connect." Moreover, "whether via video call, phone, or through random acts of kindness, many are experiencing our human connection, our shared understanding of how strange it feels to go through this pandemic, and a warm reminder that...we care for one another." Snower (2020) discusses fundamental lessons humanity learned from the COVID-19 pandemic. The conclusion that people recognized that they are interconnected in the majority of their activities is consistent with many of the aforementioned studies. The world had to admit that "one individual cannot succeed without the cooperation of others." In communities all around the world, the pandemic has revealed simultaneously "a vast sea of kindness and benevolence" as well as "the danger of ignoring our interdependence and the importance of global cooperation." In addition, COVID-19 clearly demonstrated that mankind as a whole is in the same situation independent of nation, culture, class or religion.

The pandemic changed the very attitude towards virtue ethics; namely, it showed what an underestimated power it has. In a period of uncertainty, when it is still unknown how to act and where to move, it is on virtue and moral obligations that one can rely on. Bellazzi \& Boyneburgk (2020) describe the pandemic as the unprecedented situation "within living memory...that affects everyone without distinction." The unexpectedness and impetuosity of this phenomenon seemed to leave humanity without support, after which there came an awareness of the importance of following in accordance with moral guidelines recognized by everyone. The authors describe how critical exercising virtues became and how many aspects during the pandemic required focusing on moral obligations. Further, the pandemic has demonstrated how strongly all people depend on each other; even a little event somewhere in China can seriously affect life in America and all over the world. The pandemic made people understand that all of them as a society can only perish or find a way out together. According to Jeffrey (2020), "the pandemic has demonstrated the power of shared emotion." Moreover, "disasters can reveal reserves of human solidarity and kindness," as well as reconsider the importance of these virtues.

The concept of virtue is one of the most ancient companions of man. Its basis is unshakable, but still, over the centuries, to one degree or another, it has changed, as has changed the attitude towards it. Humanity itself has developed and changed rapidly, and some aspects of recognized morality and virtues have also changed, depending on the new reality. This usually happens during global crises because it is the crisis that allows seeing what usually happens slowly and imperceptibly, and what has been growing for a long time, or vice versa, what was lacking. For example, after World War II, it became obvious to humanity that what happened should not be allowed to happen again. For a while, the world lived with a sense of solidarity, and it seemed that the virtues would now only prevail. However, people have once again forgotten that they have an impact on the world 


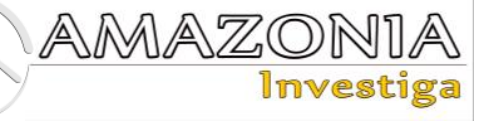

and the world on them. The pandemic became the best reminder of this.

Such virtue as solidarity deserves special attention. Many achievements of mankind are connected precisely with the fact that people are able to cooperate with each other. It is important not to forget that solidarity and altruism are originally inherent in a person. Of course, the pandemic crisis has many different negative consequences, but it definitely improved global solidarity. Many people really managed to understand that one should worry about the health of every person on Earth. In fact, there is a war between people and a virus, and every person on the planet is involved in this war, so if stability is violated anywhere in the world, then it endangers everyone. Business closures and self-isolation have affected most of the world's population, which has banded together to protect vulnerable groups, in particular, the elderly and those with impaired health. The result of all this is the greatest manifestation of solidarity in human history. Of course, in today's complex society, solidarity is much less stable and definite, but it still exists, including at the level of small groups that persist in the era of civilization in the form of a family and a community.

The results of the study showed that in different communities, solidarity manifested itself at different levels and to different degrees, it, like a sense of social responsibility, increased significantly, and people in all communities in some way or another realized and recognized the importance of these virtues.

Several phenomena that were global experiences became accompanying elements of the pandemic. Each person, in certain basic things, has experienced the same as everyone else. For example, millions of people were forced to stay at home in order to, if not stop, then at least slow down the spread of infection. The widespread wearing of masks has become a symbol of a pandemic across the globe, truly moving from personal safety to caring for others. Thus, even in the midst of such a destructive situation for human society, there is a place for humanity and genuine solidarity. For example, over the past year, there have been emotional reports in the news of how people have publicly thanked medical personnel for selflessly helping others.

In fact, the pandemic has become a real test of kindness and mutual assistance and has united people. Recovering from the initial panic, people began to realize what was happening and try to do their best to fight the infection. Many have become acutely aware of the importance of basic human priorities, including family, caring for loved ones; the observance of the rules of hygiene and the value of human life became relevant again. The studies reviewed confirmed that virtue during a pandemic has become not so much an interesting phenomenon but a necessity. Around the world, movements of solidarity began to emerge for people in difficult situations during the pandemic. Mutual assistance is increasingly being provided voluntarily and is becoming not just a measure of survival in a crisis but a new model of civic behavior. Within the framework of various communities, neighbors, although forced to observe the regime of home isolation, try not to lose heart and support each other using social networks. In addition, through the Internet and symbolic actions of solidarity, people in different countries also express support for medical workers and highlight other good deeds. As the experience of the pandemic has shown, mutual understanding and assistance, even in the most insignificant situations, can return faith in humanity.

As many studies demonstrate, communication on social networks and interaction through online platforms has become an important factor in uniting people. Rybinska, et al., (2020), state "synergies between television and the Internet have brought new ways of viewing the role of audiences and spreading perceptions of programs". The author of one article noted, in response to forced isolation, people, on the contrary, developed a desire to communicate and support each other. It can be concluded that as ironic as it may sound, after quarantine, it will no longer be possible to close within its own borders; people need to act jointly develop to reduce the damage.

Events in connection with the coronavirus pandemic will definitely go down in history. Until recently, it was not even possible to assume that people around the world would so quickly and radically reconsider their way of life and values. When all countries had to take radical action due to the explosion of the pandemic, each individual had to think about how his actions and decisions can affect others. This, in turn, called for practical wisdom and solidarity. This knowledge has always been invisibly present in people's lives, but few thought that it would have to be applied in this way. The pandemic provided such a chance; it demonstrated the enormous dependence of people on the planet on each other. This was largely due to government action; nevertheless, it seems that everyone separately 
had to think about personal responsibility. Many studies show that it is natural for people in times of threat or crisis to strive for solidarity and united efforts, to act in concert and support each other. Therefore, it is not surprising that events in the wake of the pandemic have forced people to remember and revert to virtue. During this period, people could see before their very eyes how solidarity and common efforts helped to level the crisis and, thus, to become convinced of the importance and usefulness of overwhelmingly recognized moral principles. Interestingly, the concept of virtue gained particular importance during the pandemic for the reason that it can be relied on where the law does not provide adequate support. Mutual respect, compassion, moral responsibility, and humility are by far the best approach to problemsolving, both for states and for people around the world.

The results of the given research include several findings. First, all considered studies agree that the pandemic forced people to turn to virtue ethics, rethink its importance, and recognize the need for compliance with the ethical and moral principles by all people. Second, most studies highlight solidarity as the virtue that received the most attention and significance of which people had to rethink. The other important virtues were responsibility, empathy, and compassion. Third, the main factors that made people display virtues and moral behavior were the sense of shared identity, seeking contact when confronted with a threat, and empathy. The reasons for changing attitudes towards virtue during the pandemic are facing new moral and ethical issues and the phenomenon of the global threat itself, creating an impulse for solidarity and compassion. The significance of the given research lies in the proved or emphasized the fact of the increased importance of virtue during the time of the pandemic. This finding can be applied for dealing with side effects and complications arising from the pandemic as well as for further research.

\section{Conclusions}

The current situation has taught humanity that trouble can appear unexpectedly and affect everyone to varying degrees. The pandemic has given a serious impetus for people to think about the importance of virtue and realize it as a necessity. This experience has shown the value of stability and security, the importance of wellcoordinated work of state and social systems, as well as the strength of moral responsibility. Speaking of long-term implications, given how much the concept of virtue has changed during the pandemic, the coronavirus could push humanity towards the need for civilizational unity. It is solidarity and global cooperation that can help prevent the further spread of the pandemic and build relationships between people and between countries that will contribute to general prosperity and lay the foundation for future collaborative relationships.

The key to success of the fight against the pandemic is to work together, to take care not only of neighbors but also of people living on the other side of the earth. In the light of the new era of global politics, humanity needs cooperation more than ever to solve a problem like a pandemic. Thus, the results of this study supported its original claim that the concept of virtue during the COVID-19 pandemic changed in the sense that its importance and necessity have been rethought; virtue has become not just a moral concept but a tool that allows humanity to cope with the global crisis. People again realized that virtue is not a feat but the norm of human life. The pandemic provoked a reappraisal of values, as it showed people what is really important and that it is a virtuous person who is a condition and guarantee of social prosperity.

\section{References}

Agazzi, E. (2020). The Coronavirus Pandemic and the Principle of Common Good. Bioethics Update, 6 no. 2, 63-66. https://doi.org/10.1016/j.bioet.2020.04.001.

Bellazzi, F., and Boyneburgk, K.V. (2020) COVID-19 Calls for Virtue Ethics. Journal of Law and the Biosciences, 7, no. 1, 1-8. https://doi.org/10.1093/jlb/lsaa056.

Chávez-Segura, A. (2020). Beyond COVID-19: From Crisis to Compassion. E-International Relations, May 22. https://www.eir.info/2020/05/22/beyond-covid-19-fromcrisis-to-compassion/.

Cheng, K.K., et al. (2020). Wearing Face Masks in the Community during the COVID-19 Pandemic: Altruism and Solidarity. The Lancet, 1-2. https://doi.org/10.1016/S01406736(20)30918-1.

Christner, N., et al. (2020). Prevention for Oneself or Others? Psychological and Social Factors That Explain Social Distancing During the COVID-19 Pandemic. Journal of Health Psychology, 1-12. https://doi.org/10.1177/1359105320980793.

Deutscher, E. (2020). Solidarity and Responsibility during the Coronavirus Crisis. Ad Hoc Recommendation, March 27. 


\section{$\underset{\text { AMA AZONDA }}{\text { Vnvestiga }}$}

Fahlquist, J.N. (2021). The Moral Responsibility of Governments and Individuals in the Context of the Coronavirus Pandemic. Scandinavian Journal of Public Health, 1-6. https://doi.org/10.1177/1403494821990250.

Fowers, B.J., et al. (2021). Courage, Justice, and Practical Wisdom as Key Virtues in the Era of COVID-19. Frontiers in Psychology, 12, $1-11$. https://doi.org/10.3389/fpsyg.2021.647912.

Galang, J.R., et al. (2021). Solidarity as a Companion Virtue in Response to the COVID-19 Pandemic. Journal of Public Health, 43(2), 315-316. https://doi.org/10.1093/pubmed/fdab024.

Igwe, P.A., et al. (2020). Solidarity and Social Behaviour: How Did This Help Communities to Manage COVID-19 Pandemic? International Journal of Sociology and Social Policy, 1-28. https://doi.org/10.1108/IJSSP07-2020-0276.

Jeffrey, D.I. (2020). Relational Ethical Approaches to the COVID-19 Pandemic. Journal of Medical Ethics, 46 no. 8, 495-498. https://doi.org/10.1136/medethics-2020106264

Jerry, R.H. (2020). COVID-19: Responsibility and Accountability in a World of Rationing. Journal of Law and the Biosciences, 7(1), 124. https://doi.org/10.1093/jlb/lsaa076

Jo, J., Knearem, T., Tsai, C. H., \& Carroll, J. M. (2021). COVID-19 Kindness: Patterns of Neighborly Cooperation during a Global Pandemic. In C\&T'21: Proceedings of the 10th International Conference on Communities \& Technologies-Wicked Problems in the Age of Tech, 1-14. https://doi.org/10.1145/3461564.3461587.

Mendes, A. (2020). Mind the Gap: Kindness in Uncertain Times. British Journal of Cardiac Nursing, $15(5)$ https://doi.org/10.12968/bjca.2020.0073.

Morrell, K. (2020). Values in the Age of Coronavirus: How a Disease Changed What
It Means to Live a Virtuous Life. Durham University Business School. https://www.dur.ac.uk/business/impact/socie ty/values-covid-19/.

O'Brolcháin, F., and Brereton, P. (2011). Learning from COVID-19: Virtue Ethics, Pandemics and Environmental Degradation: A Case Study Reading of the Andromeda Strain (1971) and Contagion (2011). Journal of Science Fiction and Philosophy, 4. https://philpapers.org/rec/OBRLFC.

Pfattheicher, S., et al. (2020). The Emotional Path to Action: Empathy Promotes Physical Distancing and Wearing of Face Masks During The COVID-19 Pandemic. Psychological Science, 31(11), 1363-1373. https://doi.org/10.1177/0956797620964422.

Rybinska, Yu., Guba, L., Stebaeva, O., Kuznetsova, A., \& Kovalenko, A. (2020). Media Education in Spain and Influence of Political Talk Shows on the Formation of Public Opinion. Bulletin of Zhytomyr State University named after Ivan Franko. Pedagogical Sciences, no. 102, pp. 75-85.

Snower, D. J. (2020). Fundamental Lessons from the COVID-19 Pandemic. In Opening Address of the Global Solutions Summit 2020. The World Policy Forum.

Tomasini, F. (2021). Solidarity in the Time of COVID-19? Cambridge Quarterly of Healthcare Ethics, 30(2), 234-247. https://doi.org/10.1017/S0963180120000791

Van Bavel, J.J., Baicker, K., \& Willer, R. (2020). Using Social and Behavioural Science to Support COVID-19 Pandemic Response. Nature Human Behaviour, 4(5), 460-471. https://doi.org/10.1038/s41562-020-0884-z.

Xafis, V., Schaefer, G.O., Labude, M.K., Zhu, Y., \& Hsu, L.Y. (2020). The Perfect Moral Storm: Diverse Ethical Considerations in the COVID-19 Pandemic. Asian Bioethics Review, 12, 65-83. https://doi.org/10.1007/s41649-020-00125-3 